\title{
Physicochemical and bacteriological screening of pathogenic microorganisms from aquarium water collected from katabon area in Dhaka city
}

\author{
Jannatul Mawa ${ }^{1}$, Saurab Kishore Munshi ${ }^{1}$, Amatun Nur Mou ${ }^{2}$ and Ifra Tun Nur ${ }^{1} *$ \\ ${ }^{1}$ Department of Microbiology, Stamford University Bangladesh, 51, Siddeswari Road, Dhaka-1217, Bangladesh \\ ${ }^{2}$ Biotechnology and Genetic Engineering Discipline, Khulna University, Khulna-9208, Bangladesh
}

Received 07 October 2021/Accepted 21 November 2021

\begin{abstract}
Globally, the ornamental fish business has a high demand for its popularity as well as for its profitability. However, microbial contamination, nutrient depletion and accumulation of organic materials are the major factors in an aquafarming system which can cause death of aquatic animal and causes financial losses. This study aimed to determine the physicochemical and microbiological quality of fish aquarium water. Water of different time interval after treatment $(7$ days, 20 days, 30 days, 60 days, 90 days) were taken from the different aquariums. A set of physicochemical parameters such as temperature, transparency, $\mathrm{pH}$, conductivity, dissolved oxygen, total dissolved solids, alkalinity, total hardness, conductivity were found within the approved standard concentration for fish. The present study also reveals the microbiological status of the aquaculture water where the total viable count ranging from $2.20 \times 10^{4}$ to $4.20 \times 10^{4} \mathrm{cfu} / \mathrm{ml}$. Escherichia coli, Staphylococcus spp., and Pseudomonas spp. were present in all samples. Antimicrobial susceptibility tests were also done to determine the antibiotic resistance pattern of microbes isolated from aquarium water.
\end{abstract}

Keywords: Aquarium water, Physicochemical properties, Water quality, Pathogenic microorganisms.

\section{INTRODUCTION}

Aquatic organisms require good quality water for their survival and to maintain a healthy environment. Several physicals, biological and chemical indicators are used to maintain water quality. Ornamental fish trade is gaining popularity and provides many economic and social benefits to stakeholders worldwide (1). However, the spread of potential pathogens that may cause disease in fish affects the economy of the ornamental fish business. Firstly, proper monitoring of the physicochemical parameter of water quality in aquariums is fundamental to ensure the healthy growth of the fish. Among them, $\mathrm{pH}$, chlorine and chloramine, nitrite, nitrate, and temperature, Biological Oxygen Demand (BOD), turbidity, iron, etc. are needed to be controlled. Continuous fluctuations in any one of the parameters are detrimental to the fish in the aquarium (2). After that, the microbiological quality of the water should be monitored regularly because the contamination of the water with pathogenic microorganisms may cause serious illness and even death of fish in aquariums (3). In particular, nutrient-rich and warm aquarium tank water provides suitable conditions for bacterial growth (4). High mortality of aquarium fish is reported due to bacterial contamination. Mostly, gram-negative aerobes and facultative anaerobes bacteria are isolated as causative agents of bacterial disease in fish $(5,6)$. Aeromonas spp., Citrobacter freundii, Shevanella putrefaciens and Flavobacterium columnare are common causes of hemorrhage and necrosis on the skin and base of the fins (7-13). Apart from gram-negative bacteria, gram-positive Streptococcus spp. can cause infections in ornamental fish (14). To prevent bacterial diseases good hygiene and effective sanitary practice need to follow on a regular basis. Excellent water quality can be achieved through recirculation of aquarium water, application of proper cleaning agents, reduction of fish debris and organic matter in order to reduce the stress in fish (15). Microbial contamination in ornamental fish can causes financial loss to the producers, so it is important to control microbial hazard during fish culture. Filtration, ultraviolet radiation, and ozonation proved their efficiency as an improver of water quality and combinedly they are more effective in the control of fish pathogens which reduces the occurrence of bacterial disease $(16,17)$. For the prevention of fungal growth Star gold 100-water cleaner, renamycin-animal formula tablets, star aqua spot- were available in the aquarium shops in Bangladesh (2). The most common household methods for cleaning water are bleach and vinegar. Antibiotics such as erythromycin, aminoglycosides, sulfonamide, nitrofurans, quinolones and tetracycline are widely used in aquarium water (19).

Previously, one of our research groups studied (20) the physicochemical and microbiological quality of water in fish hatcheries and reported the presence of 
microorganisms which can be harmful to humans. Although ornamental fish are not consumed by people but they are kept in household to increase beauty of indoor environment, so it has a vital role in our economy. Very few studies have studied the potential pathogens associated with ornamental fishes or their water. The objective of this study is to identify the physicochemical properties and bacteriological analysis of aquarium water used to cultivate ornamental fish.

\section{MATERIALS AND METHODS}

Study area and sampling. Total five aquarium water samples ( 7 days, 20 days, 30 days, 60 days, and 90 days) were collected from a local supplier of ornamental fish of the Dhaka division from November 10 to November 15 in 2020. Samples were collected aseptically in sterile screw-capped bottles kept in a thermal stabilizing box maintained at $25^{\circ} \mathrm{C}$, transported to the laboratory, and immediately subjected to microbiological analysis (20).

Physicochemical status of the water samples. Physicochemical properties such as, dissolved oxygen, temperature (DO), $\mathrm{pH}$, electrical conductivity (EC), salinity, total dissolved solids (TDS) and turbidity were measured for all water samples following the standard methods of American Society for Testing and Materials (ASTM) using different calibrated standard instruments (20).

Enumeration of Total viable bacteria (TVC) and Total Fecal Coliform (TFC). For enumeration of TVC and TFC, $0.1 \mathrm{ml}$ of each sample was spread onto Nutrient agar and membrane fecal coliform $(\mathrm{mFC})$ agar, respectively. For total bacterial count plates were incubated at $37^{\circ} \mathrm{C}$ for 24 hours and for obtaining fecal coliform count plates were incubated at $44.5^{\circ} \mathrm{C}$ for 24 hours $(21,22,23)$.

Identification of pathogenic microorganisms. For the isolation of E. coli, Klebsiella spp., S. aureus, and Pseudomonas spp., $0.1 \mathrm{ml}$ of each sample was spread onto MacConkey agar, Mannitol salt agar (MSA), and Cetrimide aga (HiMedia), respectively. The plates were incubated at $37^{\circ} \mathrm{C}$ for 24 hours Eosin methylene blue (EMB) agar media were further used for the observation of the production of green metallic sheen (if any) as the specific characteristic of E. coli strains. For the assessment of Salmonella spp., Shigella spp. and Vibrio spp., $0.1 \mathrm{ml}$ of each sample was spread onto xylose lysine deoxycholate (XLD) agar and thiosulfate citrate bile salt (TCBS) sucrose agar respectively. For the final identification of all isolates, severa biochemical tests were performed including the triple sugar iron test, motility, urease test, methyl red test, Voges Proskauer test, indole utilization test and the oxidase test (22)

Determination of antimicrobial susceptibility. The pathogenic isolate were examined for antibiotic susceptibility traits (either drug-resistant or sensitive) by disc diffusion assay on Mueller-Hinton agar (Difco, Detroit, MI) against commonly used antibiotics following the standard protocol Antibiotics used in the study included erythromycin $(15 \mu \mathrm{g})$, amikacin $(30$ $\mu \mathrm{g})$, tetracycline $(30 \mu \mathrm{g})$, ciprofloxacin $(5 \mu \mathrm{g})$, gentamycin $(10 \mu \mathrm{g})$ neomycin $(10 \mu \mathrm{g})$. Plates were then inverted and incubated at $37^{\circ} \mathrm{C}$ After 8 hours, plates were examined and the diameters of the zones of inhibition were measured in diameter (24)

\section{RESULTS AND DISCUSSION}

Total 13 parameters such as DO, BOD, temperature, $\mathrm{pH}, \mathrm{EC}$, salinity, TDS, turbidity, chlorine iron, and ammonia of the water samples were monitored. For all the tested samples dissolved oxygen, temperature, $\mathrm{pH}$, EC, salinity, TDS, and turbidity were found within the marginal limit except the concentration of chlorine, which was found in higher concentration $(5 \mathrm{mg} / \mathrm{l})$ in sample 5 (Table 1). Among the important parameters that need to be maintained at certain values are the $\mathrm{pH}$, chlorine and chloramine, nitrite, nitrate, and temperature. Rapid changes in any one of the parameters are detrimental to the fish in the aquarium. It is also important to maintain the quality of water because the contamination of the water with pathogenic microorganisms may cause serious illness or even death among the cultured organisms in the water (20). Pathogenic bacteria were observed in aquarium water which was further biochemically identified (Tables 2 and 3). Fecal coliforms were found in all samples and the highest load was observed in 60 days old water $\left(1.20 \times 10^{4} \mathrm{cfu} / \mathrm{ml}\right)$, Klebsiella was found in two samples which were collected from 30 days old water $\left(2.7 \times 10^{3} \mathrm{cfu} / \mathrm{ml}\right)$ and 90 days reserved water $\left(1.4 \times 10^{3} \mathrm{cfu} / \mathrm{ml}\right)$, and $E$. coli $\left(2 \times 10^{2}-2.9 \times 10^{3} \mathrm{cfu} / \mathrm{ml}\right)$ were found in all samples and were present within the range of $\left(10^{3}-10^{4} \mathrm{cfu} / \mathrm{ml}\right)$ but Salmonella spp., Shigella spp. and Vibrio spp. were absent in samples. Growth of Pseudomonas spp. was found to be $6.6 \times 10^{3} \mathrm{cfu} / \mathrm{ml}$ and present in all tested samples, likewise the presence of Staphylococcus spp. was found to be $10^{3} \mathrm{cfu} / \mathrm{ml}$ in all samples (Table 2). Presence of E. coli, Salmonella spp. and Shigella spp. was predominantly found in aquarium water $(25,26)$. Raja et al monitored the presence of Vibrio spp., Pseduomonas aeuroginosa, Bacillus cereus, Staphylococcus spp. in water samples collected from different aquaculture (27).

For most of the pathogenic isolates, higher rates of resistance were found against ciprofloxacin and neomycin (Table 4). On the other hand, most of the isolates were found to be sensitive against other tested antibiotics, mostly erythromycin and gentamycin. Highest zone of inhibition $(32 \mathrm{~mm})$ is recorded when erythromycin was applied against $E$. coli.

Assessment of microbiological quality of aquarium water is important to detect the prevalence of diseases causing microorganisms in fish. Good practice in aquarium management preventing the occurrence of cross-contamination. Avoiding cross-contamination, it is crucial to maintain hygiene for individual utensils and equipment for each system (28). Currently, the use of chloramines in water treatment is increasing over chlorine as it is much more stable and does not evaporate from the water. However, the use of a recommended dose of chloramines should be used otherwise it may convert the organic materials into some carcinogenic agents, such as chloroform and carbon tetrachloride (29). It is impossible to maintain fish in sterile water. However, a proper cleaning system can reduce, prevent, and control the occurrence of pathogenic organisms in the water body. It is necessary to ensure contamination free aquarium system to reduce microbial pathogenesis of fish and economic loss incurred by it.

\section{CONCLUSION}

From the present study, we can conclude the physicochemical parameters of water samples were within the tolerable limit. The bacterial population isolated from the water samples exhibits multiple antibiotic resistances. Microbiological load and antibiotics resistance patterns are both harmful for the aquafarming facility. Therefore, to ensure the safety of the aquafarming proper management of wastewater is important and at the same time, unprescribed and irregular incorporation of antibiotics need to be inhibited. 
Table 1. Chemical properties of the water samples.

\begin{tabular}{|c|c|c|c|c|c|c|c|c|c|c|}
\hline $\begin{array}{l}\text { Sample } \\
\text { (number } \\
\text { of days) }\end{array}$ & $\begin{array}{c}\text { Hardness } \\
(\text { ppm) }\end{array}$ & $\begin{array}{c}\text { DO } \\
(\mathrm{mg} / \mathrm{l})\end{array}$ & $\begin{array}{c}\text { Temperature } \\
\left({ }^{\circ} \mathrm{C}\right)\end{array}$ & $\begin{array}{l}\text { BOD } \\
(\mathrm{mg} / \mathrm{l})\end{array}$ & $\underset{(\mathrm{mg} / \mathrm{l})}{\operatorname{Ammonia}}$ & pH & $\begin{array}{c}\mathrm{EC} \\
(\mu \mathrm{s} / \mathrm{cm})\end{array}$ & $\begin{array}{c}\text { Salinity } \\
\text { (ppt) }\end{array}$ & $\begin{array}{c}\text { Alkalinity } \\
(\mathrm{mg} / \mathrm{l})\end{array}$ & $\begin{array}{c}\text { TDS } \\
(\mathbf{p p m})\end{array}$ \\
\hline 7 days & 24 & 6.4 & 25 & 0.2 & 0.05 & 9.5 & 344 & 0.16 & 40 & 136 \\
\hline 20 days & 31 & 6.2 & 26 & 0.7 & 0.05 & 9.6 & 476 & 0.25 & 51 & 211 \\
\hline 30 days & 27 & 5.8 & 27 & 0.1 & 0.05 & 9.7 & 541 & 0.23 & 45 & 241 \\
\hline 60 days & 34 & 4.9 & 26 & 0.3 & 0.04 & 10.1 & 372 & 0.18 & 62 & 174 \\
\hline 90 days & 29 & 4.8 & 27 & 0.1 & 0.05 & 10.4 & 362 & 0.26 & 54 & 186 \\
\hline
\end{tabular}

Table 2. Microbiological quality of aquarium water

\begin{tabular}{lccccccccc}
\hline $\begin{array}{l}\text { Water } \\
\text { sample }\end{array}$ & TVB & E. coli & TFC & $\begin{array}{c}\text { Klebsiella } \\
\text { spp. }\end{array}$ & $\begin{array}{c}\text { Salmonella } \\
\text { spp. }\end{array}$ & $\begin{array}{c}\text { Shigella } \\
\text { spp. }\end{array}$ & $\begin{array}{c}\text { Vibrio } \\
\text { spp. }\end{array}$ & $\begin{array}{c}\text { Staphylococcus } \\
\text { spp. }\end{array}$ & $\begin{array}{c}\text { Pseudomona } \\
\text { spp. }\end{array}$ \\
\hline 7days & $2.20 \times 10^{4}$ & $8.8 \times 10^{3}$ & 0 & 0 & 0 & 0 & 0 & $2.3 \times 10^{3}$ & $6.2 \times 10^{3}$ \\
20days & $2.8 \times 10^{4}$ & $1.20 \times 10^{4}$ & 0 & 0 & 0 & 0 & 0 & $1.9 \times 10^{3}$ & $1.3 \times 10^{3}$ \\
30days & $3.5 \times 10^{4}$ & $6.4 \times 10^{3}$ & 0 & $2.7 \times 10^{3}$ & 0 & 0 & 0 & $1.8 \times 10^{3}$ & $6.6 \times 10^{3}$ \\
60days & $3.63 \times 10^{4}$ & $2.50 \times 10^{4}$ & 0 & 0 & 0 & 0 & 0 & $7.2 \times 10^{3}$ & $1.4 \times 10^{3}$ \\
90days & $4.20 \times 10^{4}$ & $2.21 \times 10^{4}$ & 0 & $1.4 \times 10^{3}$ & 0 & 0 & 0 & $3.3 \times 10^{3}$ & $2.7 \times 10^{3}$ \\
\hline
\end{tabular}

Table 3. Biochemical tests of different pathogens.

\begin{tabular}{|c|c|c|c|c|c|c|c|c|c|c|c|}
\hline \multirow{2}{*}{$\begin{array}{l}\text { Assumed } \\
\text { Pathogenic } \\
\text { microorganisms }\end{array}$} & \multicolumn{4}{|c|}{ TSI } & \multirow[b]{2}{*}{ 尝 } & \multirow[b]{2}{*}{$\frac{0}{0}$} & \multirow[b]{2}{*}{$\underline{z}$} & \multirow[b]{2}{*}{$\dot{s}$} & \multirow{2}{*}{ 苞 } & \multirow{2}{*}{$\frac{\mathscr{O}}{\tilde{\pi}}$} & \multirow{2}{*}{ 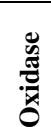 } \\
\hline & 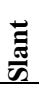 & 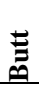 & $\underset{\tilde{J}}{\tilde{E}}$ & $\boldsymbol{n}^{N}$ & & & & & & & \\
\hline E. coli & $\mathrm{Y}$ & $\overline{\mathrm{Y}}$ & + & - & + & + & + & - & - & $+\mathrm{ve}$ & -ve \\
\hline Klebsiella spp. & Y & $\mathrm{Y}$ & + & - & + & - & - & - & + & $+\mathrm{ve}$ & -ve \\
\hline Staphylococcus spp. & Y & $\mathrm{Y}$ & - & - & + & - & + & - & - & $+\mathrm{ve}$ & -ve \\
\hline Pseudomonas spp. & $\mathrm{R}$ & Y & - & - & + & - & + & - & - & $+\mathrm{ve}$ & +ve \\
\hline
\end{tabular}

Table 4. Antimicrobial susceptibility pattern of different pathogenic isolates in the aquarium water.

\begin{tabular}{|c|c|c|c|c|c|c|}
\hline Sample & Organism & $\begin{array}{c}\text { Erythromycin } \\
(15 \mu \mathrm{g})\end{array}$ & $\begin{array}{c}\text { Amikacin } \\
(30 \mu g)\end{array}$ & $\begin{array}{c}\text { Tetracycline } \\
(30 \mu \mathrm{g})\end{array}$ & $\begin{array}{c}\text { Gentamicin } \\
(10 \mu \mathrm{g})\end{array}$ & $\begin{array}{c}\text { Ciprofloxacin } \\
(5 \mu \mathrm{g})\end{array}$ \\
\hline \multirow{4}{*}{$\mathrm{S} 1$} & E. coli & $32 \mathrm{~mm}$ & $15 \mathrm{~mm}$ & $10 \mathrm{~mm}$ & $15 \mathrm{~mm}$ & $18 \mathrm{~mm}$ \\
\hline & Pseudomonas spp. & $30 \mathrm{~mm}$ & $25 \mathrm{~mm}$ & $28 \mathrm{~mm}$ & $25 \mathrm{~mm}$ & $16 \mathrm{~mm}$ \\
\hline & Staphylococcus spp. & $28 \mathrm{~mm}$ & $16 \mathrm{~mm}$ & $24 \mathrm{~mm}$ & $28 \mathrm{~mm}$ & $17 \mathrm{~mm}$ \\
\hline & E. coli & $30 \mathrm{~mm}$ & $10 \mathrm{~mm}$ & $20 \mathrm{~mm}$ & $20 \mathrm{~mm}$ & $12 \mathrm{~mm}$ \\
\hline \multirow[t]{2}{*}{ S2 } & Staphylococcus spp. & $25 \mathrm{~mm}$ & $18 \mathrm{~mm}$ & $20 \mathrm{~mm}$ & $22 \mathrm{~mm}$ & $11 \mathrm{~mm}$ \\
\hline & Pseudomonas spp. & $28 \mathrm{~mm}$ & $23 \mathrm{~mm}$ & $27 \mathrm{~mm}$ & $26 \mathrm{~mm}$ & $21 \mathrm{~mm}$ \\
\hline \multirow{4}{*}{ S3 } & E. coli & $30 \mathrm{~mm}$ & $28 \mathrm{~mm}$ & $30 \mathrm{~mm}$ & $25 \mathrm{~mm}$ & $20 \mathrm{~mm}$ \\
\hline & Staphylococcus spp. & $27 \mathrm{~mm}$ & $18 \mathrm{~mm}$ & $29 \mathrm{~mm}$ & $24 \mathrm{~mm}$ & $19 \mathrm{~mm}$ \\
\hline & Klebsiella spp. & $28 \mathrm{~mm}$ & $20 \mathrm{~mm}$ & $15 \mathrm{~mm}$ & $25 \mathrm{~mm}$ & $18 \mathrm{~mm}$ \\
\hline & Pseudomonas spp. & $30 \mathrm{~mm}$ & $18 \mathrm{~mm}$ & $20 \mathrm{~mm}$ & $20 \mathrm{~mm}$ & $19 \mathrm{~mm}$ \\
\hline \multirow{4}{*}{ S4 } & E. coli & $32 \mathrm{~mm}$ & $8 \mathrm{~mm}$ & $22 \mathrm{~mm}$ & $25 \mathrm{~mm}$ & $10 \mathrm{~mm}$ \\
\hline & Pseudomonas spp. & $35 \mathrm{~mm}$ & $25 \mathrm{~mm}$ & $10 \mathrm{~mm}$ & $30 \mathrm{~mm}$ & $20 \mathrm{~mm}$ \\
\hline & Staphylococcus spp. & $30 \mathrm{~mm}$ & $15 \mathrm{~mm}$ & $22 \mathrm{~mm}$ & $22 \mathrm{~mm}$ & $25 \mathrm{~mm}$ \\
\hline & E. coli & $29 \mathrm{~mm}$ & $20 \mathrm{~mm}$ & $25 \mathrm{~mm}$ & $30 \mathrm{~mm}$ & $10 \mathrm{~mm}$ \\
\hline \multirow{3}{*}{ S5 } & Klebsiella spp. & $26 \mathrm{~mm}$ & $24 \mathrm{~mm}$ & $18 \mathrm{~mm}$ & $25 \mathrm{~mm}$ & $27 \mathrm{~mm}$ \\
\hline & Pseudomonas spp. & $32 \mathrm{~mm}$ & $12 \mathrm{~mm}$ & $7 \mathrm{~mm}$ & $20 \mathrm{~mm}$ & $18 \mathrm{~mm}$ \\
\hline & Staphylococcus spp. & $30 \mathrm{~mm}$ & $10 \mathrm{~mm}$ & $18 \mathrm{~mm}$ & $15 \mathrm{~mm}$ & $10 \mathrm{~mm}$ \\
\hline
\end{tabular}

\section{ACKNOWLEDGEMENTS}

Authors are thankful to the Department of Microbiology, Stamford University Bangladesh for the technical supports provided during the study.

\section{REFERENCES}

1. Alam MR, Alam J, Pattadar SN, Karim MR and Sultan Mahmud. 2016. A trend of ornamental fish business in Barisal division, Bangladesh. Int. J. Fish. Aquat. 4:263-266.

2. Lee KS, Samuel L, Kong CY and Toh SC. 2016. Water quality and microbiological risk associated with multiple antibiotic resistance (MAR) bacteria in the water of fish facility. Int. Food Res. 23:12551261.

3. Liguori G, Cavallotti I, Arnese A, Amiranda C, Anastasi D and Angelillo IF. 2010. Microbiological quality of drinking water from dispensers in Italy. BMC. Microbiol. 10:1-5. 
4. Smith KF, Behrens MD, Max LM and Daszak P. 2008. U.S. drowning in unidentified fishes: Scope, implications, and regulation of live fish import. Conserv. Lett. 1:103-109.

5. Austin B and Allen-Austin D. 1985. A review. Bacterial pathogens of fish. J. Appl. Bact. 51:483-506.

6. Brown EE and Gratzek JB. 1980. Fish Farming Handbook. AVI Publishing Co., Westport, Connecticut, $391 \mathrm{pp}$

7. Center for Food Safety and Applied Nutrition, Aeromonas Hydrophila, http://vm.cfsan.fda.gov/ mow/chap17.html. February $5^{\text {th }}$, 2004.

8. International Specialty Supply. Aeromonas hydrophila and related bacteria. Availale http://www.sproutnet.com/Reports/aeromonas_hydrophila.htm.

9. Declercq AM, Haesebrouck F, Van Den Broeck W, Bossier P and Decostere A. 2013. Columnaris disease in fish: a review with emphasis on bacterium-host interactions. Vet. Res. 44:27.

10. Citarasu T, Alfred DK, Velmurugan S, Thanga VV, Kumaran T, Michael BM et al. 2011. Isolation of Aeromonas hydrophila from infected ornamental fish hatchery during massive disease outbreaks. Int. J. Curr. Res. 2:37-41.

11. Grim CJ, Kozlov EV, Sha J, Fitts EC, Van Lier CJ, Kirtley ML et al. 2013. Characterization of Aeromonas hydrophila wound pathotypes by comparative genomic and functional analyses of virulence genes. mBio. 4:1-13.

12. Gallani SU, Sebastião FA, Valladão GMR, Boaratti AZ and Pilarsk F. 2016. Pathogenesis of mixed infection by Spironucleus sp. and Citrobacter freundii in freshwater angelfish Pterophyllum scalare. Microb. Pathog. 100:119-23.

13. Beaz-Hidalgo R, Agüeria D, Latif-Eugenín F, Yeannes MI and Figueras MJ. 2015. Molecular characterization of Shewanella and Aeromonas isolates associated with spoilage of Common carp (Cyprinus carpio). FEMS. Microbiol. Lett. 362(1):1-8.

14. Tukmechi A, Hobbenaghi R, Rahmati Holasoo H and Morvaridi A. 2009. Streptococcosis in a pet fish, Astronotus ocellatus: A case study. Int. J. Biol. Sci. 1:30-31.

15. Cardoso PHM, Moreno AM, Moreno LZ, de Oliveira $\mathrm{CH}$, Baron FdeA, Maganha SRdeL et al. 2019. Infectious diseases in aquarium ornamental pet fish: prevention and control measures. Braz. J. Vet. Res. Anim. Sci. 56:e151697.

16. Sharrer MJ and Summerfelt ST. 2007. Ozonation followed by ultraviolet irradiation provides effective bacteria inactivation in a freshwater recirculating system. Aquacult. Eng. 37:180- 91.
17. Park J, Kim P-K, Lim T and Daniels HV. 2013. Ozonation in seawater recirculating systems for black seabream Acanthopagrus schlegelii (Bleeker): effects on solids, bacteria, water clarity, and color. Aquacult. Eng. 55:1-8.

18. Awan MB, Maqbool A, Bari A and Krovacek K. 2009. Antibiotic susceptibility profile of Aeromonas spp. isolates from food in Abu Dhabi, United Arab Emirates. New Microbiol. 32:17-23.

19. Yang H, Chen S, White DG, Zhao S, McDermott P, Walker R et al. 2004. Characterization of multiple-antimicrobial-resistant Escherichia coli isolates from diseased chickens and swine in China. J. Clin. Microbiol. 42:3483-3489.

20. Nur IT, Hossain MK and Acharjee M. 2020. Study on bacteriological and physicochemical conditions of fish hatcheries water along with the antimicrobial traits. Int. J. Life Sci. 8:262-270.

21. Nur IT, Mou AN and Habiba U. 2020. Comparative microbiological analysis of four different sea fishes collected from local market in Dhaka metropolis. Food res. 4:161-165.

22. Nur IT, Baishnab R and Tethee NS. 2017. Microbiological quality analysis of domestic water collected from the slum area's people in Dhaka city. Stam. J. Microbiol. 7:19-22.

23. Shaheduzzaman M, Rahman MS and Nur IT. 2015. Influence of temperature on the growth of fecal coliform. Stam. J. Microbiol. 6:2023.

24. Akter S, Akter T, Rahman MM, Arowan SMUJ, Asaduzzaman M and Nur IT. 2020. Demonstration of in vitro anti-bacterial activity of crucial medicinal plants in Bangladesh against pathogens isolated from sputum samples. ECMI. 16.9:25-35.

25. Trust TJ and Bartlett KH. 1974. Occurrence of potential pathogens in water containing ornamental fishes. Appl. Microbiol. 28:35-40.

26. Blanch AR, Cerdà-Cuéllar M and Hispano C. 2001. Diversity of Vibrio spp. populations in several exhibition aquaria with a shared water supply. Lett. Appl. Microbiol. 33:137-43.

27. Raja K, Fernando O, Thavasi R, Jayalaksmi S and Balasubramanian T. 2006. Diversity of bacterial populations in recirculating marine aquarium with different marine ornamental fishes. Res. J. Microbiol. 5:448-452.

28. Kent ML, Feist SW, Harper C, Hoogstraten-Miller S, Mac Law J, Sánchez-Morgado JM et al. 2009. Recommendations for control of pathogens and infectious diseases in fish research facilities. Comp. Biochem. Physiol. C. Toxicol. Pharmacol. 149:240-8.

29. Dunnick JK and Melnick RL. 1993. Assessment of the carcinogenic potential of chlorinated water: experimental studies of chlorine, chloramine, and trihalomethanes. J. Natl. Cancer Inst. 85:817-2. 